\title{
Effects of pomegranate (Punica granatum L.) barks of root and stem (alcoholic extract) on the viability and fatty acids content of Echinococcus granulosus protoscolices in vitro study
}

\author{
Rana S. Al-Juwary \\ Department of Biology, College of Girls Education, University of Mosul, Mosul, Iraq \\ Email: ranaanas_aljuwary@yahoo.com
}

(Received January 5, 2018; Accepted January 24, 2018)

\begin{abstract}
The present study was aimed to determine the scolicidal effect of stem and root alcoholic extract of Punica granatum L. (Pomegranate) on the viability and fatty acids content of Ecinococcus granulosus protoscolices. The study elucidate the scolocidal effect of both stem and root extracts. Its seemed that the scolocidal effect of root extract was higher than that of stem extract ie. LC50 and LC90 of stem extract were 5 and $9 \mathrm{mg} / \mathrm{ml}$ respectively while LC50 and LC90 of root extract were 3 and $8 \mathrm{mg} / \mathrm{ml}$ respectively. GLC analysis of E. granulosus protoscolices was stated presence of nine fatty acids esters, which were Lauric (C12:0); Myrisitic (C14:0); Palmatic (C16:0); Stearic (C18:0); Archidic (C20:0); Behenic (C22:0), which were saturated fatty acids, and Oleic (C18:1); Linoleic (C18:2); Linolenic (C18:3) which were unsaturated fatty acids. Treating E.granulosus protoscolices with LC50 of pomegranate stem bark was showing slight and swing effect on fatty acid content, while treated the protoscolices with LC50 of root bark were resulted in obvious increase in short length fatty acids like Lauric, Myrisitic and Palmatic in compare with control group. In contrast the long chain fatty acids concentration like Oleic, Linoleic and Linolenic were decrease.
\end{abstract}

Keywords: Hydatids, Pomegranate bark stem, Pomegranate bark root, Gas liquid chromatography, Lipids, in vitro

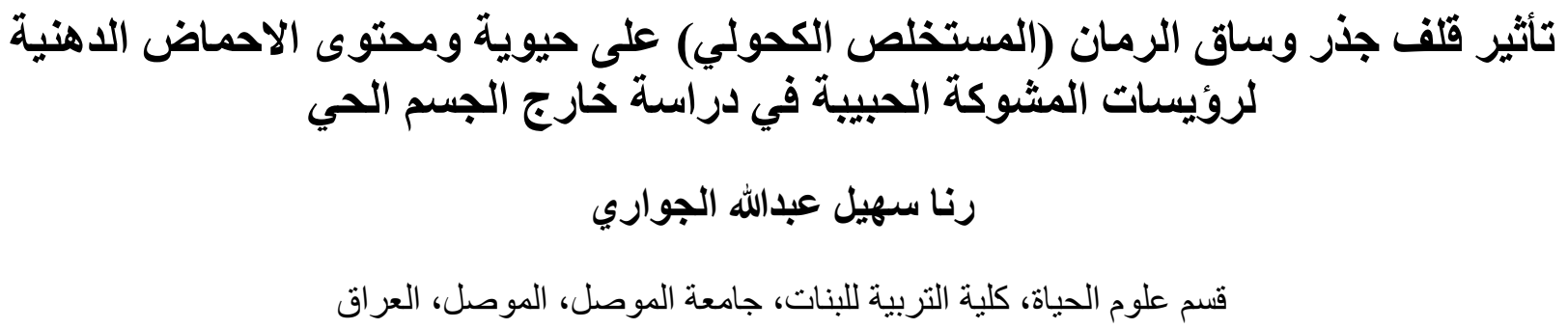

هدفت الدر اسة الحالية لبيان فعالية المستخلص الكحولي المحمض لكل من ساق وجذر الرمان كمضادات للرؤيسات الاولية للمشوكة

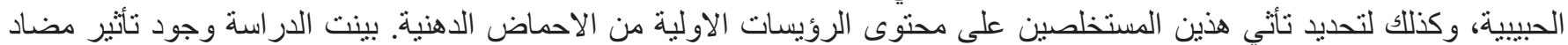

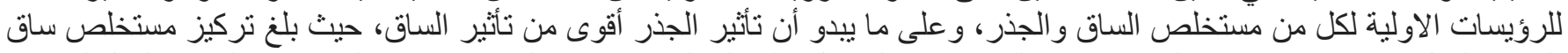

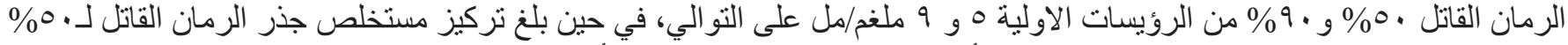

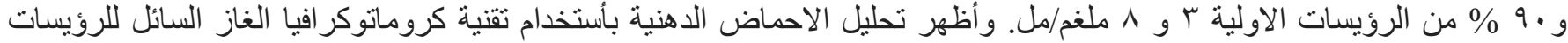

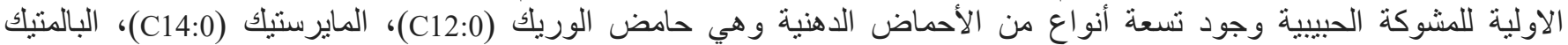

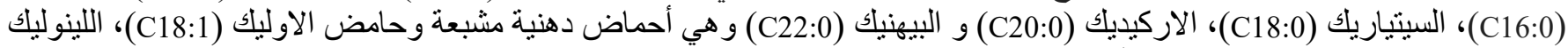

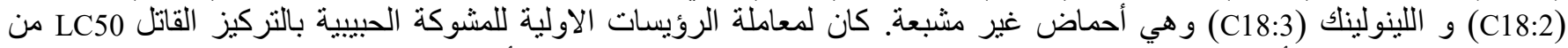

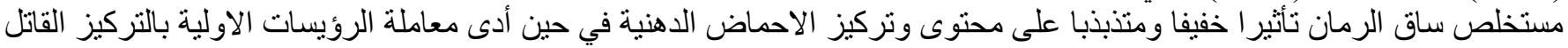


لـ LC50 من مستخلص جذر الرمان الى ازدياد واضح في تركيز الاحماض الدهنية قصيرة السلسلة مثل حامض اللاضل الوريك، المايرستيك و البالمتيك مقارنة بمجمو عة السيطرة، و على عكس ذلك الخفض الخف تركيز الاحماض الدهنية طو يلة السلسلة كالاوليك و الينوللك و اللينو لينيك.

\section{Introduction}

Hydatidosis is a highly pathogenic infection with an almost global incidence caused by the larval stage (unilocular hydatid cyst) of the cestode Echinococcus granulosus. In endemic areas it causes serious health problems for humans, livestock and wildlife animals, representing in many countries $(1,2)$.

Man and other intermediate hosts can get infection with hydatidosis then he ingest the infective eggs those shed in the outer environment by the definitive host; the dogs and other canidian animals (3). Infectious diseases are still one of the leading causes of death all over the world. Although conventional drugs are providing an effective treatments for the infections; antibiotic resistance continues to grow among key microbial pathogens. Therefore, finding new antimicrobial agents is still an important. Medicinal plants have always been a good source to find new aim for many researchers specially agents those are derived from natural products. Recently, a wide range of plants have been screened for their antimicrobial properties (4-6).

Punica granatum commonly called pomegranate, recently described as nature's power fruit, is a plant used in folkloric medicine for the treatment of various diseases $(7,8)$.

P.granatum L. (Punicaceae) a seeded or granular apple, is a delicious fruit consumed worldwide. The fruit grows in all worm country originally a native of persia, Afghanistan, China and India,then extended to Iraq and around countries (9).

Besides pomegranate peel extract with an abundance of flavonoids and tannins has been shown to have a high antioxidant activity and anti- inflammatory properties $(10,11)$ furthermore, recent studies were demonstrated its anti-cancer activity in several types of human cancers because of this plant is containing polyphenolic compounds $(12,13)$.

Methanolic extract of pomegranate fruit has been shown to induce antibacterial activity against Listeria monocytogenes, Staphylococcus aureus, Escherichia coli and Yersinia enterocolitica (4). The same as the pathogenic yeast and Candida albicans (14). Despite the many studies conducted to evaluate the efficacy of P.granatum in treating some diseases and microbial infections, much remains unknown about its antiecchinococcal effects. However, some studies have indicated that $P$. granatum has anticestodial, anti-nematoidal, anti-helmintical and antiprotozoan effects like those of $(15,16)$.

Quercetin, luteolin, and kaempferol alkaloids were isolated from pomegranate stem and root barks extracts,
Hydroquinone pyridinium alkaloid was isolated from the leaves of pomegranate (17). Various chemical constituents such as flavone glycosides (apigenin and luteolin) and tannins (punicafolin and punicalin) were separated from Pomegranate (18).

Stem and root barks were used traditionally for treating tape worms infections, (19) Tanret (1878) was isolate pelletierine from pomegranate fruits (Punica granatum L.). Other three allied alkaloids (methylpelletierine, pseudopelletierine, and isopelletierine) were separate from root and stem barks of $p$. granatum (20).

Lipids are vital biomolecules which considers a preserved source of energy when carbohydrates and glycogen are consume. Furthermore, lipids are essential components, those participate in the construction of membranes, nuclei, and mitochondria in cell (21). The conformation of lipids depends on the organic nature of fatty acids. In addition to their importance in the preservation of cellular membranes in all zoo systems, they play a key role in growth, reproduction and embryonic development (22). The ability of fatty acids $\omega-3$ and $\omega-6$ to decrease heart attack, apoplexy and carcinoma are proved, also they have a regulatory role through immune response and hypersensitivity reactions (23). The biochemical studies about lipids in the parasitic helminthes were help in developing correlation between different helminthes, and their adaptation modes in the host body (24). Lipids play an essential role in adaptation and completion of the life cycle during tapeworms and parasitic stage (25).

Fatty acids work as energy and as mediators that have ability to affect lipid metabolism and inflammatory reactions by the regulation of gene expression and cellular signaling pathways. Fatty acids $\omega-3$, for instance, are antiinflammatory, partially acting to inactivate the production of pro-inflammatory cytokine via effecting to nuclear factor-kappa B transcriptional network (26,27). Additionally, the ability of fatty acids in the protection of organs or tissues from infection due to a high concentration of fatty acids is detrimental to pathogens (28).

Therefore the present study was aimed to evaluate the efficacy of $P$. granatum root and stem barks alcoholic extract as natural antiechinococcal agents.

\section{Materials and methods}

\section{Sampling}

E. granulosus from cysts containing protoscoleces of sheep origin were obtained by aspiration of the content of cysts present in livers of naturally infected sheep. Cysts were collected during the routine work of local abattoirs in 
Mosul/ Ninavah. Samples were suspended by addition of Potassium - phosphate buffer solution pbs $(7.4 \mathrm{pH})$ after washed in several changes of sterile pbs solution (29), then refrigerated at $4^{\circ} \mathrm{C}$ and treated with alcohol extract acidified by $\mathrm{H}_{2} \mathrm{SO}_{4}(1 \mathrm{~N})$ for show the effect.

\section{Preparation of root and stem barks alcoholic extracts}

P.granatum barks of stem and root were collected from pomegranate trees in Mosul city at the period between Oct.Nov. 2016, then dried and grinded to a powder.

Alcoholic barks extract were prepared as following: $100 \mathrm{gm}$ of each bark powder were dissolved in $1 \mathrm{~L}$ acidified alcohol $\left(1 \mathrm{~N} \mathrm{H}_{2} \mathrm{SO}_{4}\right)$.

The stem and root barks were milled in to coarse powder, then extracted with ethanolic alcohol $80 \%$ that contains diluted $\mathrm{H}_{2} \mathrm{SO}_{4}(1 \mathrm{~N})$; pigments and unwanted materials were removed by shaking with chloroform, then the alcoholic extract dried to a powder to prepare stock solution for each bark were prepared at a concentration of $1 \%(1 \mathrm{gm} / 100 \mathrm{ml} \mathrm{pbs} \mathrm{pH} \mathrm{7.4)} \mathrm{ie} 10 \mathrm{mg} / \mathrm{ml}(30)$.

Estimation of lethal concentration 50 (LC50) for root and stem alcoholic extract to E.granulosus protoscolices

Gradient concentration of each extract (root and stem) were prepared as following $1,2,3,4,5,6,7,8,9$ and $10 \mathrm{mg} / \mathrm{ml}$ pbs. In addition to control group (contain pbs $\mathrm{pH} 7.4$ only).

Each concentration were put $(2 \mathrm{ml})$ in Siliconized test tube, then $(0.2 \mathrm{ml})$ of protoscolices suspension (about 1500 psc) were added to each tube. Tubes were refrigerated at $4^{\circ} \mathrm{C}$, for $24 \mathrm{hrs}$. The viability of protoscolices were determined depending on reaction with vital stain (Eosin $0.1 \%$ ) and flame cells activity (31).

Three replicates for each treatment were applied, then LC50 for root and stem bark alcoholic extract were determined according to protoscolices viability (32).

\section{Preparation of protoscolices extract}

Protoscolices suspension of $(1500 \mathrm{psc} / \mathrm{ml})$ were treated with LC50 for root and stem bark extracts, then the treated protoscolices were washed with distilled water several times, then centrifuged, then protoscolices sediment were collected, then disruped using ultrasonic disintegration (MSE), a12000 vibration/second for 30 second in ice bath four cycles of sonication were applied with the suspensions. Ultracentrifugation at $15000 \mathrm{~g} / 30$ minutes was done using (MSE) super speed ultracentrifuge. The suspension for each control group and treatments were lyophilized for the subsequent study.

\section{Fatty acids extraction}

Protoscolices extract was prepared and lyophilized according to Pappas and Narcisi method (33), using ChristBETA-Lyophilizer /Germany. Then fatty acids were extracted depending on Al-Kaisy etal. modified method
(34). $200 \mathrm{mg}$ of dried extract were dissolved in $(10 \mathrm{ml})$ of $7.5 \mathrm{~N} \mathrm{NaOH}$ (which prepared in $60 \%$ methanol). The mixture then heated to $105{ }^{\circ} \mathrm{C}$ for 90 minutes. After cooling; $12 \mathrm{ml}$ of distilled water added the mixture then acidified using 20\% sulphoric acid to adjustified $\mathrm{pH}$ to 2 . Fatty acids mixture then withdrawn with separating funnel after mixing with diethyl ether. Rotary vacuum evaporator was used to extract fatty acid mixure.

\section{GLC analysis fatty acids}

Gas liquid chromatography GLC technique (Instrument: PA. CKARD, model 4.38, USA) was used to analyze fatty acids mixture. $1 \mathrm{ml}$ of methyl ester was prepared immediately $\left(25 \mathrm{~cm}^{3}\right.$ methanol $+0.1 \mathrm{~cm}^{3}$ Acetyl chloride), then added to the crude fatty acids which were prepared before (34). Analysis of the protoscolices fatty acids and authentic fatty acids were performed in Ibn Sena Company Labs/ University of Baghdad utilized the following conditions:

Column type: SE/30, length: $3 \mathrm{~m}$, diamer: $1 / 8$ "; carrier gas and flow: Heat at $30 \mathrm{ml} /$ minute; Column temperature: $100-300{ }^{\circ} \mathrm{C}$ at $10^{\circ} \mathrm{C}$ /minute; Detecter: FID; Detecter temperature $325{ }^{\circ} \mathrm{C}$; injector temperature: $230{ }^{\circ} \mathrm{C}$; fatty acids esters were detected then, using photoelectric cell, type Schimazu-UV spectrophotometer at wavelength $230 \mathrm{~nm}$.

\section{Results}

The effect of pomegranate extracts on the viability of E.granulosus protoscolices, Its seemed that the viability of treated protoscolices were decreased with the root and stem barks concentration increase. So that treating protoscolices with $8 \mathrm{mg} / \mathrm{ml}$ of stem bark was reducing protoscolices survival to $9 \%$, while $4 \%$ of protoscolices were survive after treating with $10 \mathrm{mg} / \mathrm{ml}$ of the stem extract. The same as for root bark, which reduce survival of protoscolices to $40 \%$ when treated with $4 \mathrm{mg} / \mathrm{ml}$ and to $0 \%$ when treated with $9 \mathrm{mg} / \mathrm{ml}$ (Table 1).

It is worthy to say that pomegranate root extract had more increase effect on the viability of E. granulosus protoscolices than that of stem bark. So that LC50 and LC90 of root bark were 3 and $8 \mathrm{mg} / \mathrm{ml}$ respectively, whereas LC50 and LC90 of stem bark were 5 and $9 \mathrm{mg} / \mathrm{ml}$ respectively (Figure 1). Effect of root and stem barks of pomegranate on the fatty acids content of E. granulosus protoscolices. In the present work, according to GLC analysis and compared with retention time of authentic fatty acids (Table 2) there were nine fatty acids esters those found in the E.granulosus protoscolices. Six of them were saturated which were: Lauric acid (C12:0); Myrisitic acid (C14:0); Palmatic acid (C16:0); Stearic (C18:0); Archidic acid (C20:0) and Behenic acid (C22:0). The other three 
were unsaturated fatty acids which were Oleic acid (C18:1); Linolic acid (C18:2) and Linolenic acid (C18:3) (Figure 2) .

Treating protoscolices of E.granulosus with LC50 of root bark showed obvious change in fatty acids concentration when compared with control group (Figure 3 and Table 3). While protoscolices were treated with LC50 stem bark was showing slight and swing on the fatty acid content when compared with control group (Figure 4 and Table 3). Its seemed that long chain fatty acids concentration were decrease which include Oleic acid, Linolic acid and Linolenic acid. While short chain fatty acid were decreased which include Lauric acid, Myrisitic acid and Palmatic acid.

Table 1: Show the effect of root and stem barks extract in the viability \% of E.granulosus protoscolices in different concentrations, after $24 \mathrm{hrs}$ at $4^{\circ} \mathrm{C}$

\begin{tabular}{lccccccccccc}
\hline \multirow{2}{*}{ Barks } & \multicolumn{10}{c}{ Concentrations $\mathrm{mg} / \mathrm{ml}$} \\
\cline { 2 - 14 } & Control & 1 & 2 & 3 & 4 & 5 & 6 & 7 & 8 & 9 & 10 \\
\hline Stem & $99 \%$ & $98 \%$ & $81 \%$ & $77 \%$ & $63 \%$ & $51 \%$ & $43 \%$ & $39 \%$ & $28 \%$ & $13 \%$ & $4 \%$ \\
Root & $99 \%$ & $97 \%$ & $68 \%$ & $52 \%$ & $40 \%$ & $32 \%$ & $27 \%$ & $21 \%$ & $9 \%$ & 0 & 0 \\
\hline
\end{tabular}

* three replicates were used for each treatment,

-Initial number of protoscolices used in each treatment were $\approx 1250$ protoscolices $/ 20 \mu$ l.

Table 2: Retention time for the authentic fatty acids esters those found in E.granulosus Protoscolices using GLC technique (Instrument: PA. CKARD, USA).

\begin{tabular}{lccccccccc}
\hline $\begin{array}{l}\text { Fatty acids } \\
\text { esters }\end{array}$ & Lauric & Myristic & Palmatic & Stearic & Oleic & Linoleic & Linolenic & Arachidic & Behenic \\
\cline { 2 - 9 } & C12:0 & C14:0 & C16:0 & C18:0 & C18:1 & C18:2 & C18:3 & C20:0 & C22:0 \\
\hline $\begin{array}{l}\text { Retention time } \\
\text { (minutes) }\end{array}$ & 10.38 & 12.73 & 14.60 & 15.45 & 16.00 & 16.51 & 17.36 & 19.41 & 20.62 \\
\hline
\end{tabular}

Table 3: Types and concentration\% of fatty acid esters those found in E.granulosus protoscolices after exposure to LC50 of root and stem bark extract of pomegranate compared with control group

\begin{tabular}{lccccccccc}
\hline Fatty acids & Lauric & Myristic & Palmatic & Stearic & Oleic & Linoleic & Linolenic & Arachidic & Behenic \\
\cline { 2 - 9 } esters & C12:0 & C14:0 & C16:0 & C18:0 & C18:1 & C18:2 & C18:3 & C20:0 & C22:0 \\
\hline Control & 2.17 & 5.64 & 12.36 & 19.61 & 33.47 & 14.55 & 6.72 & 3.92 & 1.56 \\
Stem & 0 & 12.93 & 16.12 & 15.66 & 29.41 & 15.30 & 7.30 & 2.16 & 1.12 \\
Root & 12.53 & 24.70 & 13.64 & 19.79 & 16.87 & 5.80 & 3.79 & 2.37 & 0.51 \\
\hline
\end{tabular}

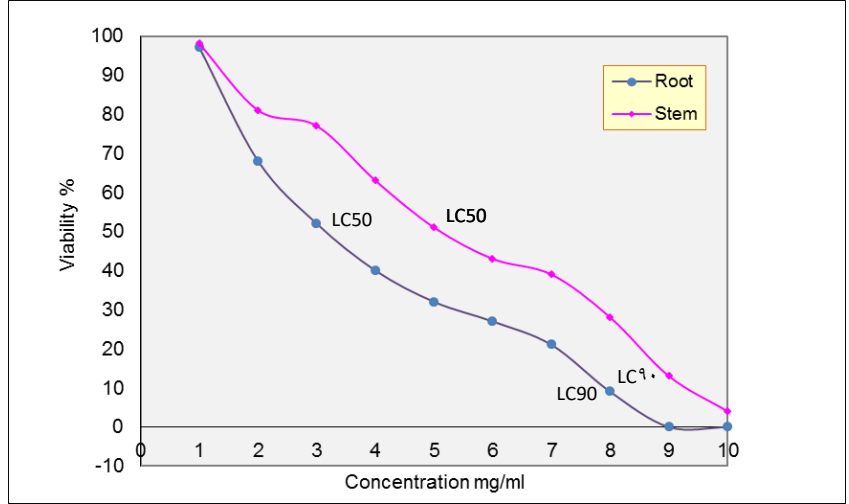

Figure 1: Lethal concentration 50 (LC50) and (LC90) Effect of root and stem bark of pomgranate on the E.granulosus protoscolices.

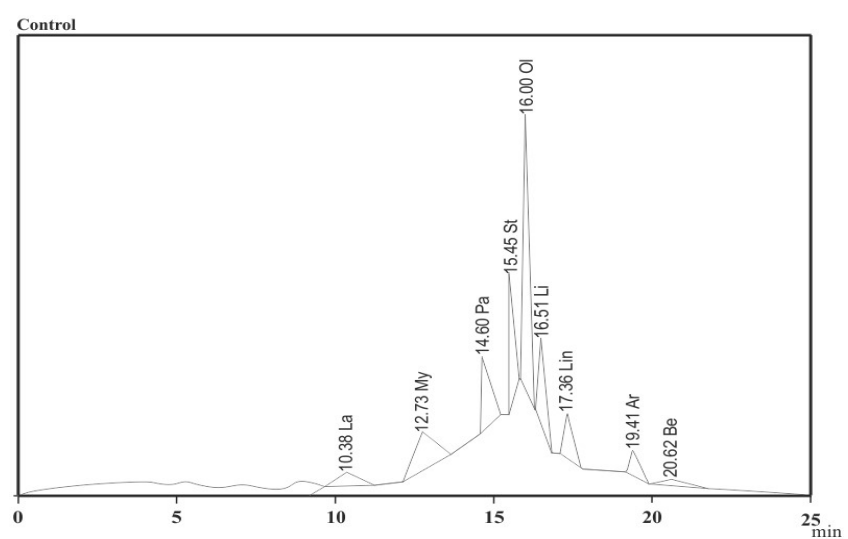

Figure 2: Chromatogram of fatty acids esters, which were separated from the extract of E.granulosus protoscolices. 


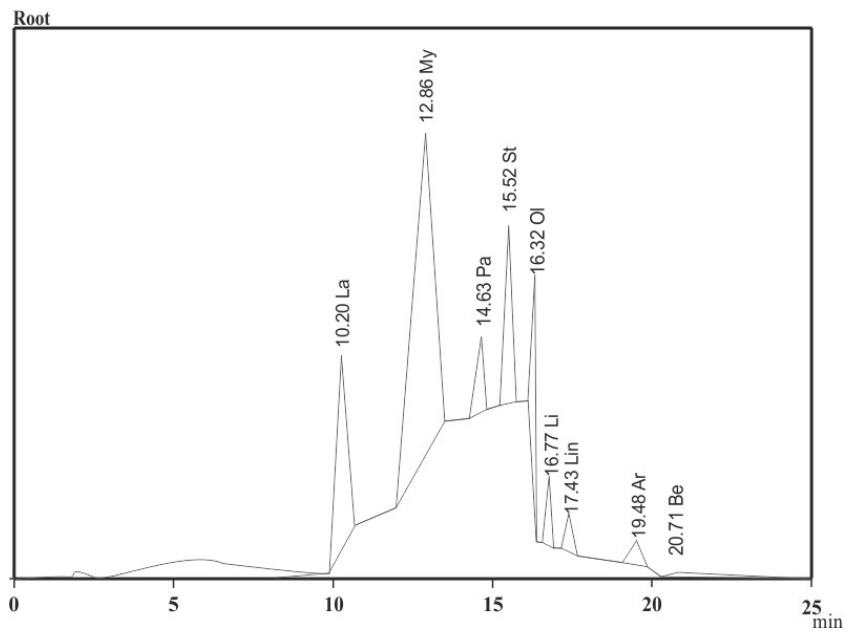

Figure 3: Chromatogram of fatty acids esters, which were separated from the extract of E.granulosus protoscolices after exposure to (LC50) of pomegranate root extract.

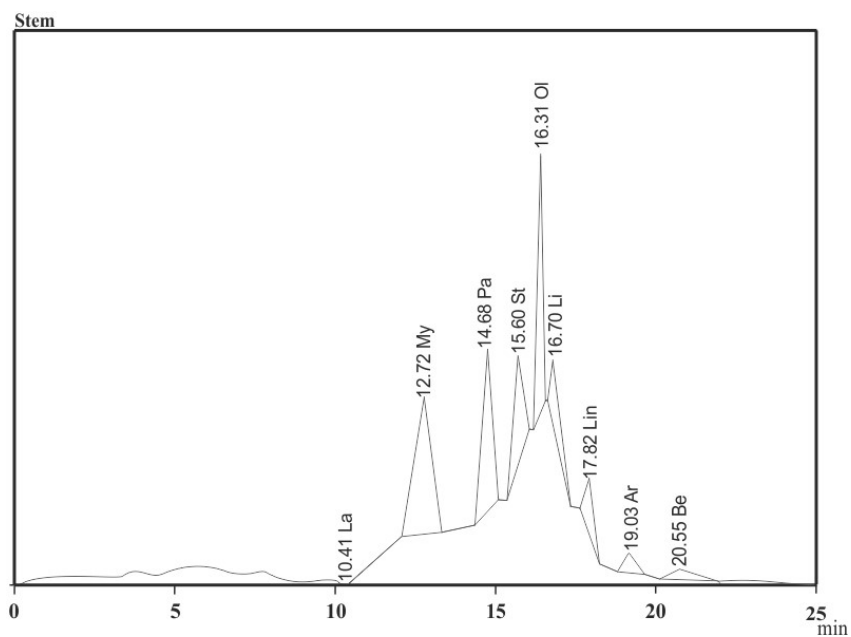

Figure 4: Chromatogram of fatty acids esters, which were separated from the extract of E.granulosus protoscolices after exposure to (LC50) of pomegranate stem extract.

\section{Discussion}

In this study, treatments compared control yielded to increase concentration \% of short chain fatty acids in specially on protoscolices extract treated with root bark significant but stem not significant at morality level 0.05 by using chi square test, In the other side there is decrease in concentration of fatty acids long chain in both treatments (stem, root) barks. The reduction was observed great relatively in protoscolices treated with LC50 from root bark, which show that treatments obstructed The elongation process in fatty acids, whereas hydatids were anaerobic parasite larvaes not depended on de novo pathways to synthase fatty acids but depended on salvage pathway by taking short chain fatty acids from host and change its structure on suitable of parasite metabolism, This is consistent with what Zayed and Hanan (35) found two concentration of Callistemon lanceolatus and Ambrosia martima were used (LC10 and LC25) for one week, snail Biomphalaria alexandrina treated with these plants were then collected and identification of fatty acids composition in snail tissue was carried out using GLC. The obtained results declared that treating snail with the plant powder was resulted in reducing concentration of both short and long fatty acids chain, and then disturbance of snail and the endo parasite physiological adaptation and thus abolishing the parasite. Furthermore, Sadeghian et al. (36) explained that pomegranate fruit skin has emerged as medicinal plant with potential antimicrobial activity gram positive Staphylococcus aureus and negative gram Pseudomonas aeroginosa bacteria. As well as against pathogenic yeast, Candida albicans on inhibition zone.and this plant used to evaluate the effect of its peel on suckling mice infected with experimental Cryptosporidium parvum (37).

From the results of the present study it could be suggested that the pomegranate root bark extract can be considered an effective anti scolocidal agents.

\section{Acknowledgements}

I extend my thanks and gratitude to Dr. Marwa Hashim Hamoushi and Dr. Anas Salim Younis Al-Mashhadani for their support throughout the research period.

\section{References}

1. Ahmadi NA, Meshkehkar M. An abattoir-based study on the prevalence and economic losses due to cystic echinococcosis in slaughtered herbivores in Ahwaz, south-western Iran. J Helminthol. 2011;1:33-39.

2. Eckert J, Conraths FJ, Tackmam K. Echinococcosis: an emerging or re- emerging zoonosis? Int J Parasitol. 2000;30:1283-1294.

3. Thompson RCA. Biology and systematics of Echinococcus and Hydatid Disease. In: Thompson RCA, Lymbery AJ. editors. Wallingford: CAB Internat. 1995;pp:373.

4. Al-Zoreky NS.Antimicrobial activity of pomegranate (Punica granatum L.) fruit peels. Int J Food Microbiol. 2009;134:244-248.

5. Upadhyay RK, Dwivedi P, Ahmad S. Screening of antibacterial activity six plant essential oils against pathogenic bacterial strains. Asian J Med Sci. 2010;2:152-158.

6. Yehia HM, Eikhadragy MF, Moneim AE.'Antimicrobial activity of pomegranate rind peel extracts. African J Microbiol. 2011;4(22:36643668 .

7. Du Lijun. "Pomegranate:Constituents Bioactivities and Pharmacokinetics", fruit. Vegetable Cereal Sci Biotchnol. 2010;77-87.

8. Ajaikumar KB, Asheef M, Babu BH, Padikkala J. The inhibition of gastric mucosal injury by Punica granatum L. (pomegranate) methanolic extract. J Ethnopharmacol. 2005;96:171-176.

9. Ross IA. Medicinal plants of the world. Humana Press, Totowa, New Jersey. 1999; pp:273-281.

10. Celik I, Temur A, Isik I. Hepatoprotective role and antioxidant capacity of pomegranate (Punica granatum) flowers infusion against 
trichloroacetic acid- exposed in rats. Food and Chemical Toxicology: An Internat J Pub British Indust Biolo Res Assoc. 2009;47:145-149.

11. Ricci D, Giamperi L,Bucchini A, Fraternale D.. "Antioxidant activity of Punica granatumfruits," Fitoterapia. 2006;77(4):310-312.

12. Adhami VM, Mukhtar H. Anti-oxidants from green tea and pomegranate for chemoprevention of prostate cancer. Mol Biotechnol. 2007;37:52-57.

13. Syed DN, Afaq F, Mukhtar H. Pomegranate derived products for cancer chemoprevention. Semin. Cancer Boil. 2007;17:377-385.

14. Endo EH, Cortez DAG, Ueda-Nakamura T, CelsoVN, Filho BPD.Potent antifungal activity of extacts and pure compound isolated from pomegranate peels and synergism with fluconazole against Candida albicans. Res Microbiol. 2010;161:534-540.

15. Subhedar S, Goswami P, Rana N, Gupta A. Shukla, P. Herba alternatives: Anthelmintic activity of Punica granatum (Pomegranate). Int J Drug Disco Herbal Res. 2011;(3):150-152.

16. El-Sherbini GT, Shoukry NM. Invitro effect pomegranate peel extract on Trichomonas tenax. Life Science J Egypt Soc. Parasitol. 2012;9(3):791-797.

17. Schmidt A, Mordhorst $\mathrm{T}$, Nieger $\mathrm{M}$. Investigation of a betainic alkaloid from Punica granatum. Nat Prod Res.2005;19:541-650.

18. Nawwar MA, Hussein SA, Merfort I. NMR spectral analysis of polyphenols from Punica granatum. Phytochem. 1994;36:793-798.

19. Tanret, CCR. Isolation of pelletierine. Acad Sci.1878; 86:1270-1272.

20. El-Sakka MA. Phytochemistry alkaloids. 3rd edition.2010;pp:7-22.

21. Deb AC. Fundamentals of biochemistry. New Central Book Agency (P) Ltd. London, 2011;pp:932.

22. Tocher D. Metabolism and functions of lipid and fatty acids in teleost fish. Rev Fisher Sci. 2003;11:107-184.

23. Harris WS. Fish oil supplementation: Evidence for health benefits. Cleveland Clinic J Med. 2004;71(3):221-226.

24. Sood MI. Histochemical, biochemical and immunological studies in Haemonchus contortus (Nematoda: Trichostrongy-Ioidea an Indian perspective. J Parasitic Dis. 2006;30(1):4-15.

25. Sato S, Hirayama T, Hirazawa N. Lipid content and fatty acid composition of the monogenean Neobenedenia girella and comparison between the parasite and host fish species. Parasitol. 2008;135:967-975.
26. Boutros C, Somasundar P, Razzak A, Helton S, Espat NJ Omega-3 fatty acids: investigations from cytokine regulation to pancreatic cancer gene suppression. Arch Surg. 2010;145:515-520.

27. Martin JM, Stapleton RD. Omega-3 fatty acids in critical illness. Nutr Rev. 2010;68:531-541.

28. Tchkonia T, Morbeck DE, Von Zglinicki T, Van Deursen J, Lustgarten J, Scrable H, Khosla S, Jensen MD, Kirkland JL. Fat tissue, aging, and cellular senescence. Aging Cell. 2010;9:667-684.

29. Farjou IB, Al-Hussainawi SS. Effect of mebendazole on the survival hydatid protoscolices of Echinococcus granulosus in vitro and in vivo. J Fac Med Baghdad. 1982;26(4):33-44.

30. Evans WC. Treaus and Evans Pharmacognosy. 4th edn. W B. Saunders Com limited, V. P. India: 1997;pp:340-408.

31. Symth JD, Barret S. Procedures for testing the viability of human hydatid cysts following surgical removal especially after chemotherapy. Trans J Soc Trop Med Hyg. 1980;74(6):49-52.

32. Al-Hammoshi HM. Effects of Crude Alkaloids Isolated from Peganum harmala Seeds on the Growth and Metabolism of Leishmania tropica Promastigotes. J Raf Sci. 2011;22:(1):17-32.

33. Pappas PW, Narcisi EM. A comparison of membrane-bound enzymes, the isolated brush border plasma membranes of the cestodes Hymenolepis diminuta and H. microstoma. Parasitol. 1982;84:391396.

34. 34.Al-Kaisy MT, Hadwan HA, Humoud M, Hussen AK. Determination of citric acid and oxalic acid in fermented solutions of Aspergillus niger by gas-liquid chromatography. Iraqi J Microbiol. 1991;3(1):170-174.

35. Zayed N, Hanan FA.Induced changes in the fatty acid profile of Biomphalaria alexanderia molluscan host to Shistosoma mansoni using two sublethal concentrations of selected plant molluscicides. Eygept Giza. J Appl Sci Res. 2012;8(7):3103-3111.

36. 36. Sadeghian A, Ghorbani A, Mohamadi A, Rakhshandeh H. Antimicrobial activity of aqueous and methanolic extracts of pomegranate fruit skin. Avicenna J Phytomed. 2011;1(2):67-73.

37. Al-Mathal EM, Alsalem AM.Pomegranate (Punica granatum) peel is effective in murine model of experimental Cryptosporidium parvum.Exper Parasitol. 2012;131:350-357. 